\title{
Discrepancy of blood pressure between arms: a case of left subclavian artery occlusion
}

\author{
Naoki Yamamoto 지 , Akihiro Dejima 다, Kenkou Hasatani
}

Department of Internal Medicine, Suzu General Hospital, Suzu, Ishikawa, Japan

\section{Correspondence to} Dr Naoki Yamamoto; ny0724jp@gmail.com

Accepted 19 April 2021

\section{Check for updates}

(C) BMJ Publishing Group Limited 2021. No commercial re-use. See rights and permissions. Published by BMJ.

To cite: Yamamoto N,
Dejima A, Hasatani K. BMJ
Case Rep 2021;14:e242025.
doi:10.1136/bcr-2021-
242025

\section{DESCRIPTION}

A 65-year-old man with no significant medical history presented to the hospital for regular examination. $\mathrm{He}$ denied arm claudication, constitutional symptoms, back pain or any traumatic injuries. He had smoked 1-2 packs of cigarette per day for over 40 years. $\mathrm{He}$ had been taking medications for diabetes mellitus, hypertension and dyslipidaemia for 8 years. Vital signs showed a blood pressure of 90/62 $\mathrm{mm} \mathrm{Hg}$ on his left arm and $122 / 66 \mathrm{~mm} \mathrm{Hg}$ on his right arm; however, the rest of his vital signs were normal. On physical examination, there was no evidence of bruits or neurological symptoms. Laboratory studies showed C reactive protein (CRP) level of $0.05 \mathrm{mg} / \mathrm{dL}$ (reference range $<0.3 \mathrm{mg} / \mathrm{dL}$ ). An enhanced CT showed the left subclavian artery was occluded from the proximal to the origin of left vertebral artery (figure 1). Coronary arteriography showed 50\% stenosis in both the left diagonal branch and left posterior descending artery. The left subclavian artery was not enhanced immediately after ascending aortography but was found to be enhanced a few seconds later. This suggested that the left vertebral artery retrogradely supplied the left subclavian artery. He received antiplatelet therapy and continued risk modifications with a diagnosis of left subclavian artery occlusion.

Subclavian artery occlusion is characterised by discrepancy of blood pressure between arms. Blood flow of the branchial artery is supplied from the contralateral vertebral artery to the ipsilateral artery, retrogradely. ${ }^{1}$ As a result, ipsilateral blood pressure is lower.

Although some patients show arm claudication and neurological symptoms due to vertebrobasilar ischaemia, most patients are asymptomatic. In

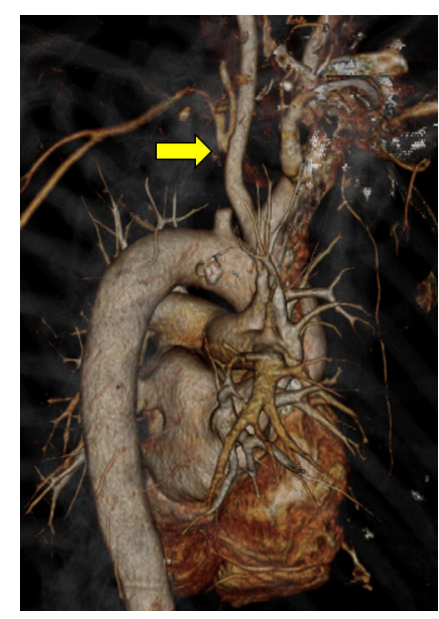

Figure 1 Left subclavian occlusion from the proximal to the origin of left vertebral artery on three-dimensional CT.

\section{Learning points}

- Subclavian stenosis is associated with total and cardiovascular disease (CVD) mortality independent of CVD risk factors.

- Discrepancy of blood pressure between both arms could help to identify patients who need further vascular assessment.

asymptomatic patients, hypertension could be overlooked when blood pressure is measured by the arm of subclavian artery stenosis. ${ }^{2}$

Differential diagnoses for discrepancy of blood pressure include atherosclerosis, Takayasu's arteritis, aortic dissection, congenital diseases and compression in the thoracic outlet. Atherosclerosis is the most common cause of subclavian artery stenosis. History-taking of risk factors for atherosclerosis and traumatic injuries is important. Younger female patients with elevations of body temperature and CRP levels are suggestive of Takayasu's arteritis. MR angiography or CT angiography can be used to confirm the presence of subclavian stenosis. Duplex ultrasonography is accessible and inexpensive, but it depends on operator's skills.

Symptomatic patients are treated with surgical bypass or endovascular intervention, while asymptomatic patients are treated with antithrombotic therapy. ${ }^{3}$ It is important to control hypertension, diabetes mellitus and dyslipidaemia in addition to smoking cessation.

Subclavian stenosis is associated with total and cardiovascular disease (CVD) mortality independent of CVD risk factors. ${ }^{4}$ Discrepancy of blood pressure for more than $10-15 \mathrm{~mm} \mathrm{Hg}$ between both arms could help to identify patients who need further vascular assessment. ${ }^{5}$ Evaluating bilateral blood pressure is non-invasive and helpful in screening before angiography.

Contributors NY and AD made substantial contributions to conception and design and have been involved in drafting the manuscript. AD and $\mathrm{KH}$ approved the final version to be published.

Funding The authors have not declared a specific grant for this research from any funding agency in the public, commercial or not-for-profit sectors.

Competing interests None declared.

Patient consent for publication Obtained.

Provenance and peer review Not commissioned; externally peer reviewed.

Naoki Yamamoto http://orcid.org/0000-0002-4113-0499 Akihiro Dejima http://orcid.org/0000-0002-8422-2406 
Images in...

\section{REFERENCES}

1 Aithal JK, Ulrich M. Images in clinical medicine. Subclavian steal syndrome. N Engl J Med 2010;363:e15.

2 Brguljan-Hitij J, Ambrosio G, Žlahtič T. Systolic murmur in disguise: subclavian artery stenosis as an overlooked cause of missed case of hypertension. Blood Press $2021 ; 30: 75-8$
3 Potter BJ, Pinto DS. Subclavian steal syndrome. Circulation 2014;129:2320-3.

4 Aboyans V, Criqui MH, McDermott MM, et al. The vital prognosis of subclavian stenosis. J Am Coll Cardiol 2007;49:1540-5.

5 Clark CE, Taylor RS, Shore AC, et al. Association of a difference in systolic blood pressure between arms with vascular disease and mortality: a systematic review and meta-analysis. Lancet 2012;379:905-14.

Copyright 2021 BMJ Publishing Group. All rights reserved. For permission to reuse any of this content visit

https://www.bmj.com/company/products-services/rights-and-licensing/permissions/

BMJ Case Report Fellows may re-use this article for personal use and teaching without any further permission.

Become a Fellow of BMJ Case Reports today and you can:

- Submit as many cases as you like

- Enjoy fast sympathetic peer review and rapid publication of accepted articles

- Access all the published articles

- Re-use any of the published material for personal use and teaching without further permission

\section{Customer Service}

If you have any further queries about your subscription, please contact our customer services team on +44 (0) 2071111105 or via email at support@bmj.com.

Visit casereports.bmj.com for more articles like this and to become a Fellow 